\title{
PERANCANGAN ADMIN SiS+ BERBASIS ONLINE UNTUK MEMPERMUDAH KINERJA ADMIN DALAM MEMONITORING DATA SiS+
}

\author{
Hani Dewi Ariessanti ${ }^{1}$ \\ Robbyul Awal Amrullah ${ }^{2}$ \\ Amalia Syahidah ${ }^{3}$ \\ Dosen STMIK RAHARJA Tangerang ${ }^{1,2}$ \\ STMIK RAHARJA Jurusan Sistem Informasi ${ }^{3}$ \\ Jl. Jendral Sudirman No. 40, Modernland, Tangerang ${ }^{1,2,3}$ \\ E-mail: hani.dewi@raharja.info ${ }^{1}$, robby@hspacademy.com ${ }^{2}$, amalia.syahidah@raharja.info ${ }^{3}$
}

\begin{abstract}
ABSTRAK
Peran komputer sangat penting pada teknologi informasi sebagai media atau alat bantu dalam memproses suatu pekerjaan untuk menghasilkan informasi berkualitas yang digunakan untuk keperluan pribadi, bisnis, pemerintahan beserta pendidikan.Pada Perguruan Tinggi Raharja saat ini memiliki sistem pelayanan yang menyediakan seluruh kebutuhan dokumen bagi mahasiswa berbasis online.Sistem yang memberikan pelayanan bagi mahasiswa Perguruan Tinggi Raharja dalam memberikan informasi mengenai Kartu Hasil Studi (KHS) mahasiswa. Tabel Indeks Prestasi Komulatif (IPK). Menyediakan daftar nilai layanan formulir yang dapat digunakan oleh mahasiswa dalam mengikuti kegiatan perkuliahan dan sebagainya secara cepat dan real-time.SiS+ di Perguruan Tinggi Raharja dioperasikan oleh seorang admin.Admin SiS+ Pada perguruan Tinggi Raharja merupakan orang yang berinteraksi langsung dengan SiS+.Sistem Admin SiS+ hadir untuk menunjang kerja admin dalam mengoperasikan data yang terpusat pada SiS+.Pada pengoperasian data sebelumnya, masih menggunakan database.Pengoperasian admin SiS+ selama ini masih memiliki kendala.Diantaranya masih dilakukan dengan pemanggilan data dengan MySQL.Dan admin mengalami kendala dalam kecepatan dalam pencarian dan pembaharuan data. System Admin SiS+ ini dibuat dengan menggunakan Yii Framework dan Bootstrap.Diharapkan sistem Admin SiS+ ini bisa membantu Admin dari segi keefektifan dalam melakuan pengkinian (Edit, Add, Delete) data.Dan memaksimalkan kinerja admin dalam melakukan pengkinian data.
\end{abstract}

Kata kunci: Admin, SiS+, SQL,

\begin{abstract}
The role of computers is very important in information technology as a medium or tool in a work process to produce quality information that is used for personal purposes, businesses, governments and their education. In Higher Education Prog currently have systems that provide all required services to students based online document. Systems that provide services for university students Prog in providing information about Card Study Results (KHS) students.Table cumulative grade point (GPA). Provides a list of values that form the service can be used by students to follow lectures and so quickly and in realtime. SiS + in Higher Education Prog operated by an admin. SiS Admin Prog + At Higher education is a person who interacts directly with SiS +. System Admin SiS + present to support the work of administrators in operating a centralized data on SiS + . In the operation of previous data, they use the database. Operation admin SiS + for this still has obstacles. Among them is still done by calling the data with MySQL. And admin experience constraints in speed in searching and updating data. System Admin SiS + is made using Yii Framework and Bootstrap. SiS + system is expected Admin Admin can help in
\end{abstract}


terms of effectiveness in updating melakuan (Edit, Add, Delete) data. And maximize performance in the admin update data.

Key Word: Admin, SiS+, SQL

\section{PENDAHULUAN}

Perkembangan teknologi informasi khususnya komputer semakin berkembang pesat di berbagai bidang pekerjaaan dan jasa. Kebanyakan orang berpendapat bahwa dengan adanya pemanfaatan komputer pada bidang pekerjaannya, maka pekerjaan mereka akan semakin mudah dan cepat. Maka dari itu peran komputer sangat penting pada teknologi informasi sebagai media atau alat bantu dalam memproses suatu pekerjaan untuk menghasilkan informasi berkualitas yang digunakan untuk keperluan pribadi, bisnis, pemerintahan beserta pendidikan. Dalam pelaksanannya, dibutuhkan seorang admin untuk mengoperasikan sistem pada suatu perusahaan besar maupun kecil demi kelancaran sistem yang berjalan pada perusahaan tersebut.Admin adalah orang yang bertugas mengurus hal-hal yang bersifat administratif.Pada prakteknya dalam dunia kerja, Admin bisa memiliki arti yang berbeda-beda, tergantung dari jenis atau bidang pekerjaan.Jika bekerja di bidang pembukuan, admin bisa saja menjadi posisi yang dipercaya untuk memastikan semua data tercatat dan tersusun dengan rapi.Namun jika dalam industri online atau teknologi internet, yang sedang marak belakangan ini, profesi admin adalah posisi yang dipercayakan sebagai tokoh eksekutor dalam menjalankan sebuah website, blog atau akun media sosial yang dimiliki perusahaan.Tapi dalam sistem atau sebuah website, admin adalah orang bertanggungjawab dalam pengoperasian seluruh website atau sistem tersebut.Perguruan Tinggi Raharja terdapat sebuah sistem informasi pelayanan akademik yang dapat diakses secara online yaitu $\mathrm{SiS}+. \mathrm{SiS}+$ diakses melalui sisplus.raharja.ac.id.

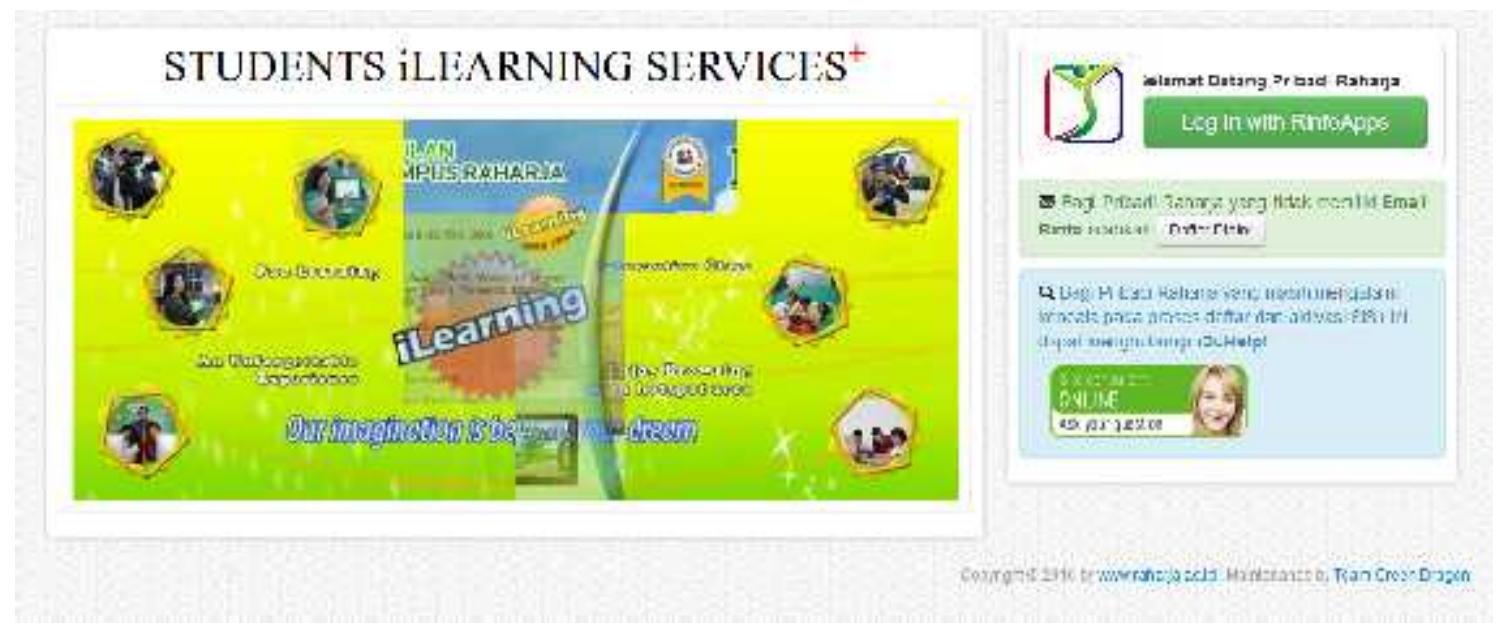

Sumber: $\underline{\text { http://sisplus.raharja.ac.id/ }}$

\section{Gambar 1.Homepage SiS+}

Dalam sistem informasi tersebut, terdapat berbagai data dan informasi seputar mahasiswa mencakup keseluruhan. Yaitu, Kartu Hasil Studi (KHS) mahasiswa, Tabel Indeks Prestasi Komulatif (IPK),Daftar Nilai, Dokumen KKP, TA/Skripsi, Menyediakan layanan formulir yang 
dapat digunakan oleh mahasiswa dalam mengikuti kegiatan perkuliahan dan sebagainya secara cepat dan real-time.

Namun pada sistem yang berjalan, terdapat berbagai kekurangan seperti saat admin mengakses data dan informasi seluruh mahasiswa masih sebatas akses melalui database atau bisa disebut manual.Karena hanya bisa diakses melalui database, untuk memantau dan memperbaharui data mahasiswa membutuhkan waktu yang tidak sedikit, dan kurangnya keefektifan dalam pengaksesan.Dan hanya bisa dilakukan oleh admin.Oleh karena itu dari permasalahan tersebut maka perlu adanya suatu sistem untuk mempermudah kinerja admin dalam memantau dan memperbaharui data mahasiswa seperti biodata, Ipk, daftar nilai, dan lainlain.

\section{PERMASALAHAN}

Dalam masa perkuliahan, mahasiswa sangat membutuhkan fasilitas yang memadai dan memaksimalkan demi kelancaran selama masa perkuliahan.Karena semakin banyaknya kebutuhan mahasiswa atas kelengkapan formulir yang diperlukan pada perguruan Tinggi Raharja, ada sebuah sistem berbasis online untuk memfasilitasi mahasiswa dalam melakukan kelengkapan dokumen selama perkuliahan, yaitu $\mathrm{SiS}+$.dan bisa diakses dengan mengunjungi Sisplus.raharja.ac.id.

Dalam pelaksanaannya, admin yang akan melakukan pengkinian (pemhapusan, penambahan, pembaharuan) data, admin masih mengalami kendala, diantaranya: Belum adanya system informasi yang bisa membantu kerja admin dalam mengoperasikan seluruh data yang berhubungan dengan mahasiswa dalam SiS+. Jadi selama proses berjalan, admin hanya menggunakan database dengan melakukan pemanggilan data dengan Query .

\section{HASIL DAN PEMBAHASAN}

\section{Pengertian SiS+}

SiS+ adalah singkatan dari (Student Ilearning Sevice Plus) $)^{\sharp y a i t u ~ s i s t e m ~ y a n g ~}$ memberikan pelayanan bagi mahasiswa dan mahasiswi pada Perguruan Tinggi Raharja dalam memberikan informasi kelengkapan dokumen selama perkuliahan. Fungsi SiS+ adalah untuk menyediakan kelengkapan dokumen bagi mahasiswa. Contoh dokumen yang disediakan mengenai:

a. Kartu Hasil Studi (KHS) mahasiswa,

b. Tabel Indeks Prestasi Komulatif (IPK),

c. Daftar Nilai, Dokumen KKP, TA/Skripsi,

d. Menyediakan layanan formulir yang dapat digunakan oleh mahasiswa dalam mengikuti kegiatan perkuliahan dan sebagainya secara cepat dan real-time.

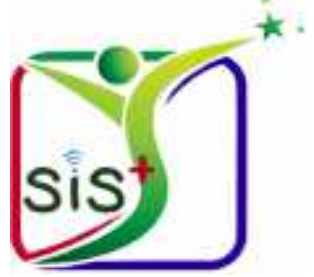

Sumber :sisplus.raharja.ac.id

Gambar 2. Logo SiS+ 
Maka dari itu, dengan adanya SIS+ dapat mempermudah mahasiswa dalam memperoleh informasi yang dibutuhkan dalam kegiatan perkuliahan, selain itu SIS+ memiliki beberapa kelebihan, diantaranya :

\begin{tabular}{|c|c|c|c|}
\hline \multicolumn{4}{|c|}{ 1. Segi Mahasiswa } \\
\hline & SIS & & SIS+ \\
\hline$x$ & $\begin{array}{l}\text { Harus datang ke } \\
\text { kampus. (lokal) }\end{array}$ & $\sqrt{ }$ & Tidak harus datang ke kampus. (online) \\
\hline $\mathrm{x}$ & Keluhan antri. & $\sqrt{ }$ & Tidak antri. \\
\hline $\mathrm{x}$ & Keluhan PRC rusak. & $\sqrt{ }$ & $\begin{array}{l}\text { Mengakses SIS+ tidak menggunakan PRC melainkan Login } \\
\text { with Rinfo Apps. }\end{array}$ \\
\hline \multicolumn{4}{|c|}{ 2. Segi Infrastruktur } \\
\hline & SIS & & SIS+ \\
\hline $\mathrm{x}$ & $\begin{array}{l}\text { Harus menyiapkan } \\
\text { banyak komputer. }\end{array}$ & $\sqrt{ }$ & $\begin{array}{l}\text { Tidak perlu menyiapkan banyak komputer karena bisa } \\
\text { dilakukan di rumah atau dimanapun dengan komputer/laptop } \\
\text { sendiri }\end{array}$ \\
\hline $\mathrm{X}$ & $\begin{array}{l}\text { Harus menyiapkan } \\
\text { banyak swipe card. }\end{array}$ & $\sqrt{ }$ & Tidak perlu swipe card karena menggunakan akun email Rinfo. \\
\hline $\mathrm{x}$ & Jaringan terputus. & $\sqrt{ }$ & $\begin{array}{l}\text { Bisa menggunakan modem sendiri atau wifi yang disediakan } \\
\text { dikampus. }\end{array}$ \\
\hline $\mathrm{X}$ & $\begin{array}{l}\text { Persediaan tinta dan } \\
\text { kertas yang banyak. }\end{array}$ & $\sqrt{ }$ & $\begin{array}{l}\text { Meminimalisir penggunaan tinta dan kertas yg banyak, karena } \\
\text { bisa di simpan di komputer/laptop sendiri. }\end{array}$ \\
\hline
\end{tabular}

Dengan adanya SIS+ ini diharapkan segala kekurangan pada sistem SIS bisa teratasi dan SIS+ dapat melayani mahasiswa dalam hal pengaksesan informasi seputar kebutuhan mahasiswa selama daam kegiatan perkuliahan dengan optimal.

Selain itu, terdapat 6 kelebihan lain dalam sistem SIS+ :

1. Dapat diakses kapanpun dan dimanapun, 24 jam 7 hari 365 hari.

2. Single Sign On (SSO) with Email Rinfo.

3. Simple, powerful, and easy to used.

4. Compatible all device.

5. Easy Get Data with Smart Searching.

6. Data berupa daftar nilai dan formulir online dapat di download dan disimpan dalam bentuk PDF. 


\section{LITERATURE REVIEW}

Literature review adalah uraian tentang teori, temuan, dan bahan penelitian lainnya yang diperoleh dari bahan acuan untuk dijadikan landasan kegiatan penelitian untuk menyusun kerangka pemikiran yang jelas dari perumusan masalah yang ingin diteliti. ${ }^{[3]}$

Literature review berisi ulasan, rangkuman, dan pemikiran penulis tentang beberapa sumber pustaka (artikel, buku, slide, informasi dari internet, dll) tentang topik yang dibahas. Literature review yang baik harus bersifat relevan, mutakhir, dan memadai. Landasan teori, tinjauan teori, dan tinjauan pustaka merupakan beberapa cara untuk melakukan literature review.

1. Pada penelitian yang berjudul "Perancangan SiS+ Menggunakan Metode Yii Framework Pada Peguruan Tinggi Raharja" yang ditulis oleh Moh. Iqbal Awi Makaram pada Januari 2015. Metode pengembangan yang dipakai ialah metode "waterfall". Berdasarkan analisa yang dilakukan penulis dan masalah-masalah yang dihadapi dalam SIS adalah penggunaannya yang masih menggukan swipe card card jika hal "swipe card" ini rusak/hilang maka mahasiswa tidak dapat menggunakan SIS. Perangkat lunak SIS+ merupakan sebuah sistem informasi berbasis web dan dibuat dengan Yii Framework menggunakan bahasa pemrograman PHP. "Database management system" (DBMS) yang digunakan dalam perangkat lunak ini adalah MySQL. ${ }^{[4]}$

2. Penelitian yang dilakukan oleh Untung Rahardja, Khanna Tiara, dan Ray Indra Taufik Wijaya dengan judul "Penerapan Rinfo Sebagai Media Pendukung Untuk Proses Pembelajaran Pada Perguruan Tinggi Raharja". Dari hasil penelitian ini menunjukkan bahwa Rinfo ini adalah Gmail, yang di adaptasi dari Google Platform dengan ciri khas raharja.info sebagai domainnya.Rinfo ini adalah media komunikasi sekaliguas alat pendukung dalam prses pembelajaran di Perguruan Tinggi Raharja. Karena selain terintegrasi dengan TPi, Rinfo ini pun terhubung pula dengan alat penunjang pembelajaran lainnya, seperti Docs, Drive, Sites dan alat penunjang lainnya. ${ }^{[8]}$

3. Penelitian yang dilakukan oleh Dwi Maya Suhainingsih yang berjudul "Pengembangan SiS+ Konsultasi Sebagai Monitoring Pelayanan Dosen dan Mahasiswa Studi Kasus: STMIK Raharja" Bentuk sistem yang di kembangkan ini adalah online, sehingga dosen bisa melakukan konsultasi dimana saja dan kapan saja. Metode yang digunakan adalah metode deskriptif dengan mengidentifikasi permasalahan terlebih dahulu, selain itu model pengembangan yang digunakan oleh peneliti berupa waterfall dari analisa permasalahan sampai tahap pemeliharaan program. ${ }^{[10]}$

4. Penelitian yang dilakukan oleh Singgih Aji Pangestu dengan judul "Pemanfaatan Website Raharja.ac.id Sebagai Media Informasi dan Upload Artikel untuk Ns-CCIT Menggunakan Framework Yii”. Di Perguruan Tinggi Raharja, kini hadir sebuah program baru yang dikenal dengan NSCCIT yang merupakan sebuah Seminar Nasional and Call for Paper yang saat ini di bangun sebagai sebuah wadah untuk mendiskusikan hasil penelitian melalui sebuah seminar. Dengan dibuatnya penelitian mengenai NSCCIT atau National Seminar and Call For Paper, diharapkan dapat menjadi solusi terbaik bagi seluruh civitas akademika untuk mengkomunikasikan dan mendiskusikan masalah - masalah yang hendak diteliti dan saling membantu dalam pemecahan masalah. ${ }^{[1]}$

Dari keempat literature review yang ada, telah banyak penelitian mengenai metode Penerapan sistem berbasis online atau sistem yang menggunakan metode Yii Framework. Namun dapat disimpulkan pula bahwa belum ada peneliti yang secara khusus membahas mengenai Sistem admin berbasis online.Dimana seorang admin dapat melakukan pengkinian data (Edit, 
Add, Delete) data dan mengoperasikan seluruh data dalam SiS+, hingga memaksimalkan kinerja admin.

\section{PEMECAHAN MASALAH}

SiS+ adalah kepanjangan dari Student iLearning Service Plus merupakan perkembangan dari SIS.Dimana SiS+ adalah sistem informasi pelayanan akademik yang dapat diakses secara online. SiS+ diakses melalui sisplus.raharja.ac.id .Dalam sistem informasi tersebut, terdapat berbagai data dan informasi seputar mahasiswa mencakup keseluruhan.Baik biodata, Ipk, daftar nilai, dan lain-lain yang dikelola oleh admin.Setelah dianalisis ternyata admin $\mathrm{SiS}+$ masih mengalami beberapa kendala. Diataranya: Belum adanya system yang bisa membantu admin dalam mengoperasikan seluruh data yang berhubungan dengan $\mathrm{SiS}+$. Karna hanya menggunakan database, jika akan melakukan pengkinian (penghapusa, penambahan, dan pembaharuan) data, admin harus masuk ke database, lalu melakukan pemanggilan data dengan Query MySQL.

\section{Use Case Diagram pada SiS+}

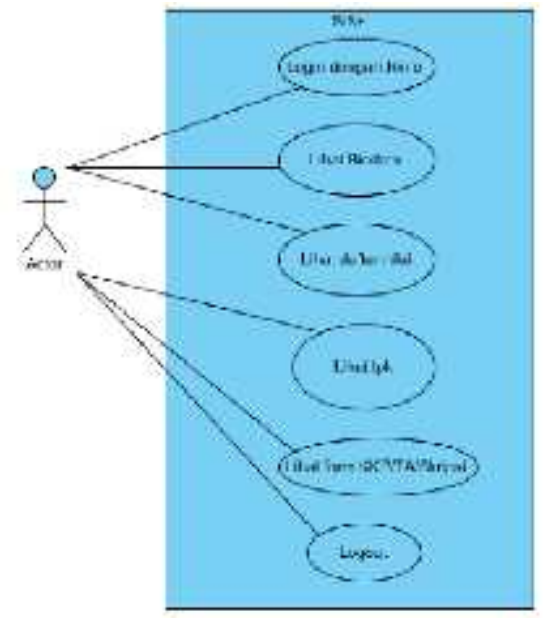

Gambar 3. Use Case SiS+

Gambar diatas menjelaskan tentang alur yang bisa dilakukan oleh mahasiswa dalam mengakses sisplus.raharja.ac.id.Pertama, mahasiswa diharuskan login dengan menggunakan email Rinfo yang sudah diaktivasi terlebih dahulu.Lalu, mahasiswa bisa melihat biodata, melihat daftar nilai seluruh matakuliah, melihat ipk pada semester tertentu, melihat dan mencetak kelengkapan dokumen KKP/TA/Skripsi. Dan diakhiri dengan logout

\section{Metodelogi penelitian (Strategi)}

Langkah-langkah yang tertuang didalam strategi project yang merupakan sebuah proses pencapaian guna meningkatkan Sistem Admin SiS+ untuk memaksimalkan kinerja admin SiS+ dalam melakukan pembaharuan, penambahan maupun penghapusan seluruh data yang terdapat pada SiS + pada Perguruan Tinggi Raharja, dan telah dibuatkan 12 strategi seperti yang ada pada gambar dibawah ini : 


\section{Tabel 1.Eliminasi dari hasil elisitasi 12 Strategi yang dilakukan} pada Sistem Admin SiS+

\begin{tabular}{|c|c|c|}
\hline $\mathrm{Nc}$ & Sิt:aitgi & Stans \\
\hline 1 & Mesauapilhan Mrau Aktivati Sist+ & $\sqrt{1}$ \\
\hline 2 & $\begin{array}{l}\text { Menmapilkna Mesu Update Nilad } \\
\text { Mahsciova }\end{array}$ & ; \\
\hline 4 & M-rannquilb.xn Muen Famel Yim piesan & $s$ \\
\hline 4 & $\begin{array}{l}\text { Measuapilkan mexu Data Małatiswa } \\
\text { Ejufuth }\end{array}$ & 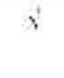 \\
\hline$s$ & Menampillau menu Beda Iimikutum & $s^{\prime}$ \\
\hline 6 & 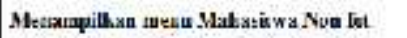 & $s$ \\
\hline 7 & 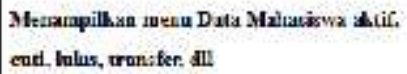 & $\checkmark$ \\
\hline 8 & Mecsanquilsan mezu Dats Duseu & $\checkmark$ \\
\hline 9 & $\begin{array}{l}\text { Monanupilkon Men Tpdate Sirom; } \\
\text { Mahastowa }\end{array}$ & $\therefore$ \\
\hline 19 & Mesarapilhan Mrau Updaik Jurusasvishia & $\checkmark$ \\
\hline II & Mesanupillan favicon pada Sistery & $\checkmark$ \\
\hline 12 & Mrnanipilkan Linga pailn skarm & $\therefore$ \\
\hline
\end{tabular}

\section{Metode Analisa (Analisa S.W.O.T)}

Menurut Rangkuti (2011:199) ditentukan oleh kombinasi faktor internal dan external.Kedua faktor tersebut harus dipertimbangkan dalam analisis SWOT. SWOT adalah singkatan dari lingkungan internal strengths dan weaknessserta lingkungan external opportunities dan threats yang dihadapi dunia bisnis.Analisa SWOT membandingkan antara faktor external peluang(opportunities) dan ancaman (threats) dengan faktor internal kekuatan (strengths) dan kelemahan (weakness)".

1. Strengths

a. Bisa diakses melalui web Browser (Online)

b. Login hanya dengan email Rinfo (SSO)

c. Update data lebih mudah karna sudah ada pembagian hak akses pada masingmasing divisi

2. Weakness

a. Belum terintegrasi dengan sistem lain

b. Sistem belum userfriendly dalam tampilan

c. Belum tersupport untuk versi mobile

3. Threats
a. Server down
b. Human error

4. Opportunities

a. Memungkinkan untuk dilakukan pengembangan kedalam versi mobile 


\section{Use Case Diagram Pada Sistem Admin SiS+}

Use Case Diagram ${ }^{[14]}$ memperlihatkan himpunan use case dan aktor-aktor (suatu jenis kasus dari kelas). Diagram ini terutama sangat penting untuk mengorganisasi dan memodelkan perilaku dari suatu sistem yang dibutuhkan serta diharapkan pengguna

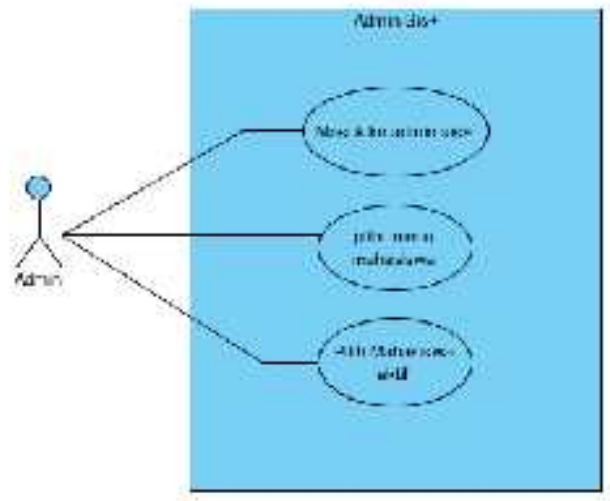

\section{Gambar 4. Use Case Diagram Sistem Admin SiS+}

Gambar diatas menjelaskan tentang pengambilan contoh untuk mencari jumlah mahasiswa aktif dalam database admin SiS+. Pertama, admin harus masuk ke database SiS+, lalu melakukan pencarian data dengan pemanggilan menggunakan Query SQL. Dan admin akan mendapatkan hasil yang dicari. Hal yang sama dilakukan saat akan melakukan penghapusan, pembaharuan, dan penambahan data.

\section{Flowchart}

Flowchart merupakan gambaran dalam bentuk diagram alir dari algoritma-algoritma dalam suatu program, yang menyatakan arah alur program tersebut. Berikut adalah beberapa simbol yang digunakan dalam menggambar suatu flowchart dijelaskan pada tabel (Pahlevy. 2010).

Flowchart yang dijelaskan pada gambar dibawah ini adalah dengan pengambilan kasus tentang pencarian daftar nilai seluruh matakuliah pada sisplus.raharja.ac.id 


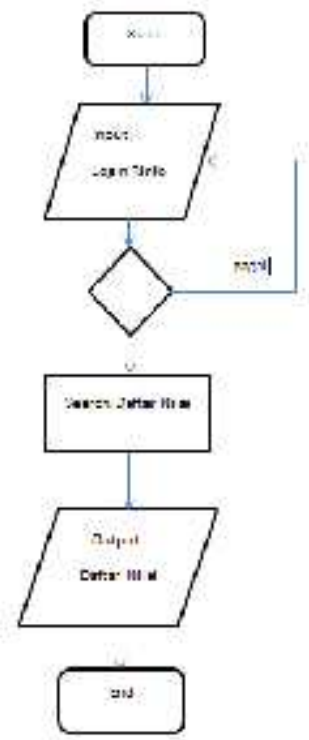

Gambar 5. Flowchat pada SiS+

Pada gambar diatas menjelaskan tentang alur pada sisplus.raharja.ac.id dengan kasus pencarian daftar nilai seluruh matakuliah.Yang berisi proses-proses alur sistem. Mulai dari start, input yaitu login menggunakan email Rinfo, searching Daftar Nilai, serta mendapatkan output berupa daftar nilai seluruh matakuliah.

\section{IMPEMENTASI}

Sistem Admin SiS+ sedang dalam tahap implementasi oleh admin SiS+.Didalam sistem ini, admin diberi kemudahan yaitu dapat melakukan perubahan, pembaharuan, penghapusa, penambahan data melalui menu menu yang sudah disediakan didalam sistem tersebut.Dan dengan fasilitas tombol Edit di beberapa menu yang diperlukan.Dan tidak perlu lagi dilakukan dengan pemanggilan data melalui Query SQL.

\section{a. Tampilan menu utama}

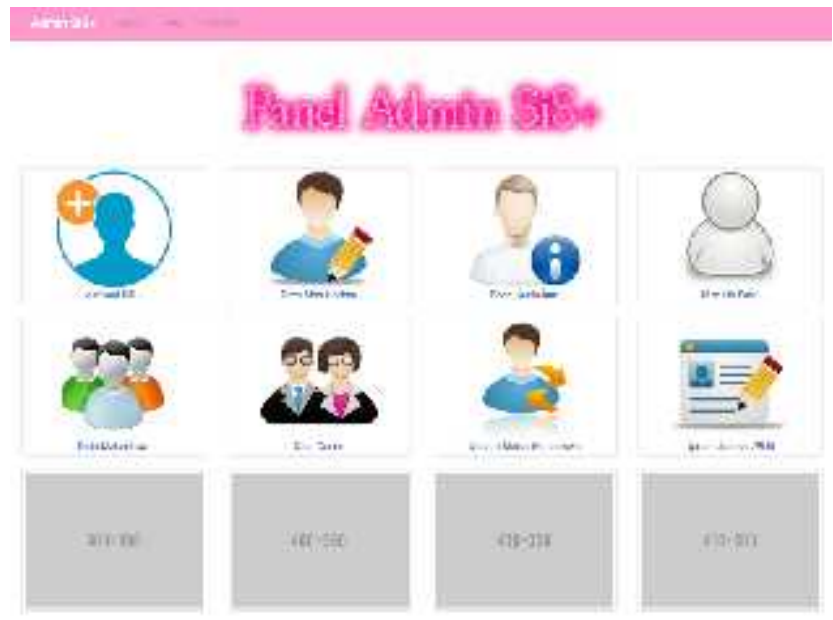

Gambar 6. Tampilan menu utama 
Gambar diatas menjelaskan tentang tampilan menu utama pada Sistem Admin SiS+.yaitu tampilan dimana terlihat daftar menu yang dibutuhkan oleh admin.

\section{b. Tampilan Menu Mahasiswa Non Foto}

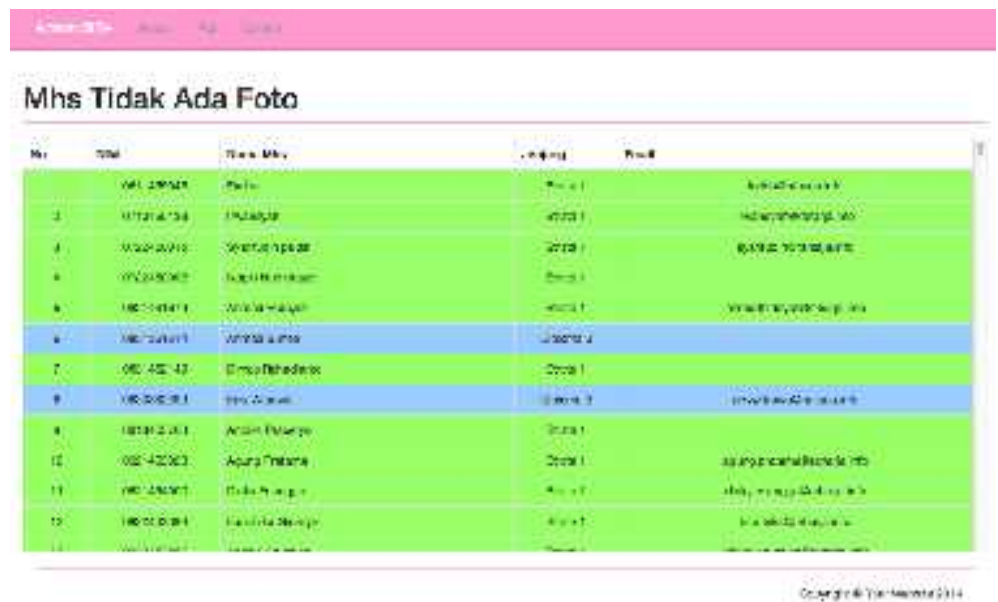

\section{Gambar 7. Tampilan Menu Mahasiswa Non Foto}

Gambar diatas menjelaskan tentang informasi daftar mahasiswa yang belum mempunyai foto dalam akun SiS+ nya. Jika mahasiswa ingin melakukan pengupdate an foto, maka akan dieksekusi oleh PIC Update Foto SiS+

\section{c. Tampilan Menu Manage Data SiS+}

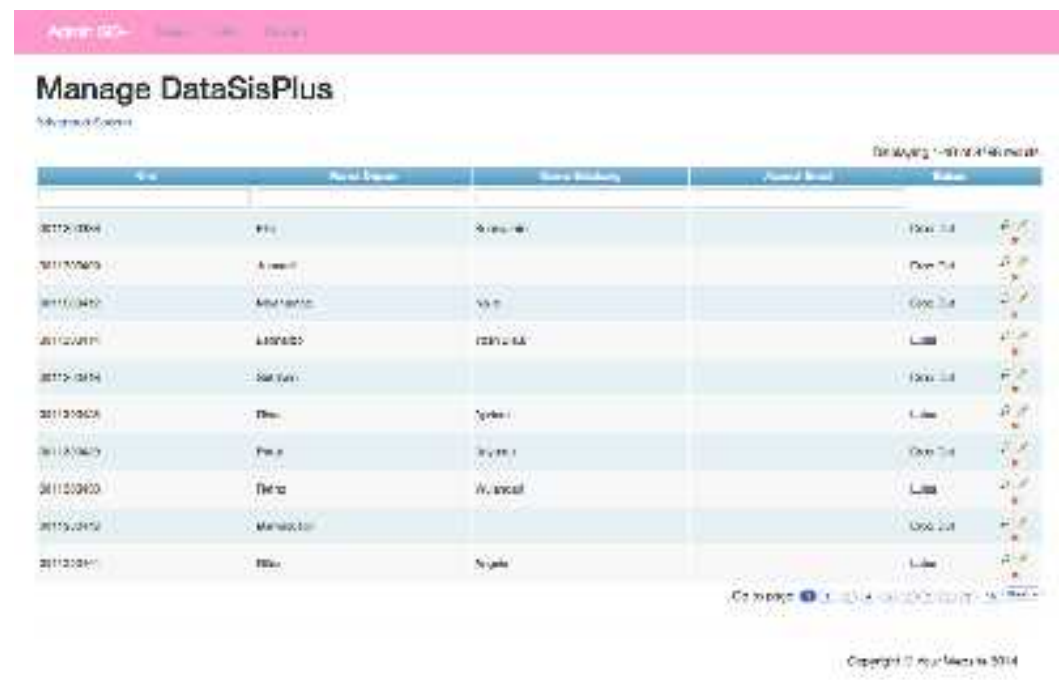

\section{Gambar 8. Tampilan menu manage data SiS+}

Gambar diatas berfungsi sebagai informasi mahasiswa yang sudah aktivasi dan yang belum aktivasi SiS+.Dan menu ini diakses oleh PIC Aktivasi SiS+. Hanya PIC Aktivasi Sis+ yang bisa melakukan pengeditan pada menu ini. 


\section{d. Tampilan Menu Data Mahasiswa}

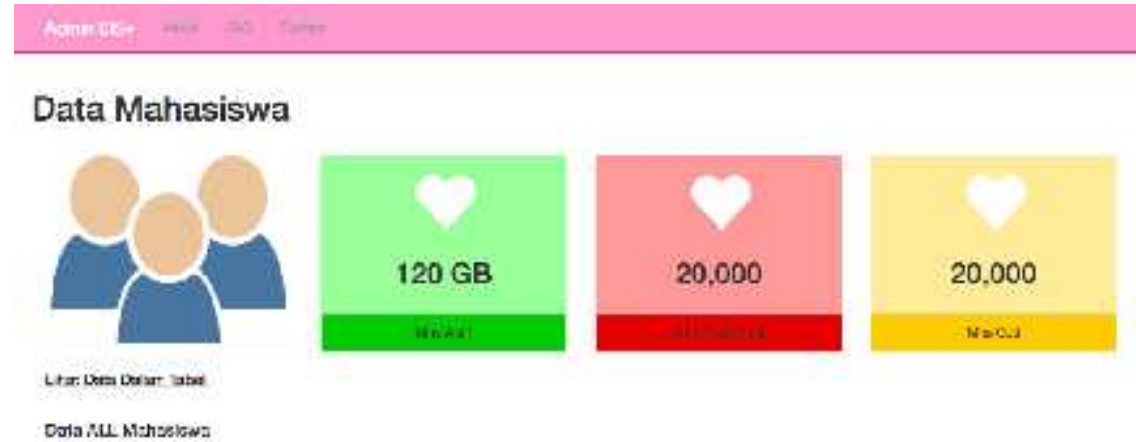

Costanc now wosm 35 .

\section{Gambar 9. Tampilan menu data mahasiswa}

Pada gambar diatas dijelaskan bahwa menu diatas berfungsi untuk memberikan informasi dari segi jumlah mahasiswa saja. Untuk data yang lebih lengkap, bisa mengklik tombol Lihat Dalam Table yang tertera pada menu diatas

\section{e. Tampilan Menu Manage Update Mahasiswa}

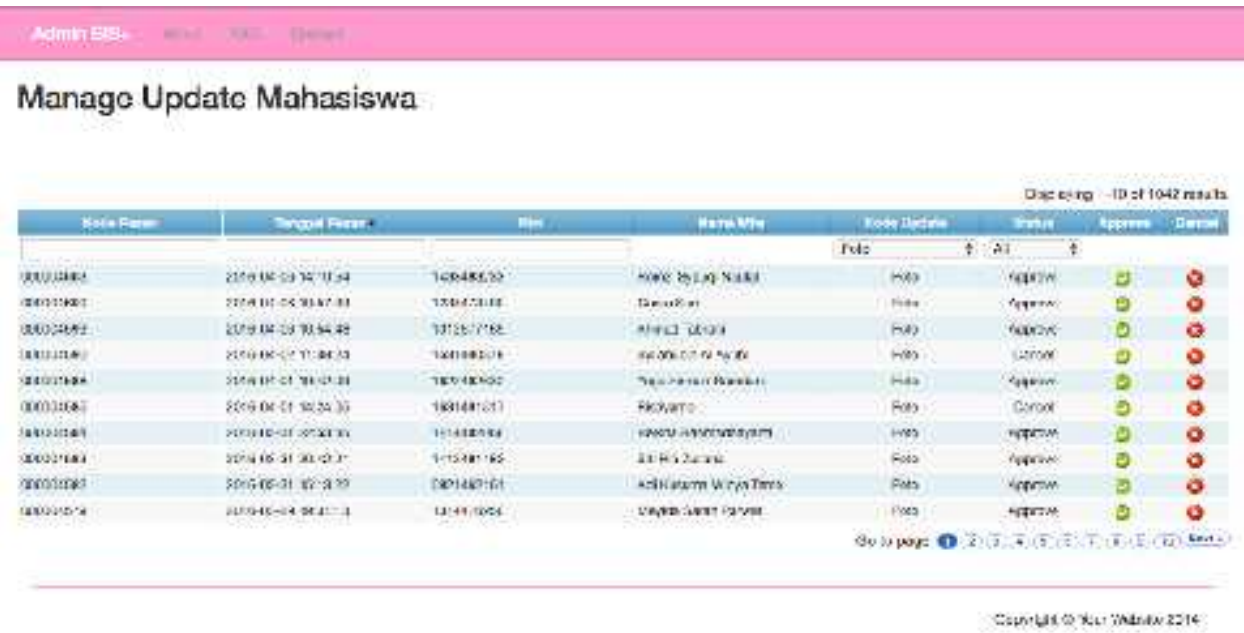

Gambar 10. Tampilan menu manage update mahasiswa

Gambar diatas menjelaskan tentang menu yang berfungsi untuk melakukan pengeditan seluruh data pada SiS+. 


\section{KESIMPULAN}

Dari hasil penelitian yang telah dilakukan, ada beberapa kesimpulan yang dapat dikemukakan sebagai berikut :

1. Sistem yang berjalan pada sistem admin $\mathrm{SiS}+$ adalah, admin yang masih menggunakan sistem database dengan melakukan pemanggilan data dengan menggunakan Query SQL.

2. Membuat sistem informasi admin SiS+ online dengan menggunakan Yii framework dalam pembuatan sistem yang sebelumnya masih menggunakan database dan dilakukan dengan pemanggilan data dengan Query SQL. Menggunakan Boostrap untuk mendesain tampilan pada Sistem yang akan dibangun. Menggunakan PHPMyAdmin untuk penyimpanan database data pada sistem yang akan dibangun. Menggunakan otorisasi hak akses kepada masing masing PIC untuk mengakses sistem yang akan dibangun.

3. Sistem informasi Admin $\mathrm{SiS}+$ ini adalah sistem yang dirancang khusus untuk meningkatkan kinerja admin dalam melakukan pembaharuan, penambahan, maupun penghapusan data pada keseluruhan data pada SiS+. Dan meningkatkan mutu pelayanan kepada mahasiswa dan berfungsi untuk memberikan informasi mengenai segala kebutuhan perkuliahan para mahasiswa.

\section{DAFTAR PUSTAKA}

[1] Rasdiana, Erlita 2015."Pengembangan Formulir Online Menggunakan QR Code pada SiS+ di Perguruan Tinggi Raharja".Skripsi. STMIK Raharja: Tangerang

[2] Rumoma, Nurhasni 2016. "Penerapan Sistem Validasi TA/Skripsi, KKP \& IS Pada Online Jadwal Rencana Studi Plus (OJRS+) Di Perguruan Tinggi”. Skripsi. STMIK Raharja: Tangerang

[3] Rangkuti, Freddy. 2011. "Teknik Menyusun Strategi Korporat Yang Efektif Plus Cara Mengelola Kinerja Dan Risiko SWOT Balanced Scorecard". Jakarta: Gramedia Pustaka Utama

[4] Hasibuan, Zainal A. 2011. Metodologi Penelitian Pada Bidang Ilmu Komputer Dan Teknologi Informasi: Konsep, Teknik, Dan Aplikasi. Jakarta: Fakultas Ilmu Komputer Universitas Indonesia.

[5] Warsito, Ary Budi, Muhamad Yusup, and Iqbal Makaram."Perancangan SIS+ Menggunakan Metode YII Framework Pada Perguruan Tinggi Raharja."CCIT Journal (2015).

[6] Rahardja, Untung, Khanna Tiara, Ray Indra Taufik Wijaya "Penerapan Rinfo Sebagai Media Pendukung Untuk Proses Pembelajaran Pada Perguruan Tinggi Raharja" CCIT Journal(2014).

[7] Ariessanti, Hani Dewi, Erick Febriyanto, Nida Hanifah "Pelayanan Sistem iDuHelp! (iLearning Education Help) Dengan Menggunakan Sistem Survey Pada Perguruan Tinggi Raharja" CCIT Journal (2014)

[8] Warsito, Ary Budi, Untung Rahardja, Dwi Maya Suhainingsih "Pengembangan SiS+ Konsultasi Sebagai Monitoring Pelayanan Dosen dan Mahasiswa Studi Kasus: STMIK Raharja". CCIT Journal (2015)

[9] Handayani Indri, Ary Budi Warsito, Singgih Aji Pangestu "Pemanfaatan Website Raharja.ac.id Sebagai Media Informasi dan Upload Artikel Untuk Ns-CCIT Menggunakan Framework Yii” CCIT Journal (2015) 
[10] Pahlevy, Randy, Tesar. 2011. Rancang Bangun Sistem pendukung Keputusan Menentukan penerima Beasiswa dengan Menggunakan metode Simpele Additive Weighting(SAW).Skripsi Program Studi Tehnik Informatika. Surabaya,Indonesia: Universitas Pembangunan Nasional "Veteran". 